\title{
Primary Malignant Fibrous Histiocytoma of the Kidney: Report of a Case
}

\author{
Böbreğin Primer Malign Fibröz Histiyositomu: Olgu Sunumu
}

\author{
Nilay ŞEN TÜRK, Canan KELTEN, Nihal ÖZKALAY ÖZDEMIR, Ender DÜZCAN
}

Department of Pathology, Pamukkale University, Faculty of Medicine, DENIZLI, TURKEY

\section{ABSTRACT}

Primary renal malignant fibrous histiocytoma is extremely rare. The prognosis is generally poor because of the high rate of local recurrence even if radical surgery is performed. We report a case of primary renal malignant fibrous histiocytoma in a 43-year-old woman.

A well-defined renal mass $(10 \times 9 \times 7 \mathrm{~cm})$ with lobulated contour was revealedbyabdominalultrasonographyand computerized tomography in our patient who presented with left-flank pain. The contralateral kidney and renal functions were normal. No other primary tumor focus was detected by screening performed to exclude a metastasis to the kidney. However, a nodule consistent with metastasis was identified in the liver. The patient underwent left radical nephrectomy. A huge, yellowish-white, partly necrotic neoplasm infiltrating the renal parenchyma, perirenal fat and adrenal tissue was revealed by gross examination. Microscopically, the tumor was composed of pleomorphic spindle to polygonal cells arranged in fascicles and storiform structures with extensive necrosis. Twelve mitotic figures were noted in 10 high power fields. Immunohistochemical staining for vimentin and CD68 were positive whereas pan-cytokeratin, smooth muscle actin, S-100, HMB-45 and desmin were negative. "A pleomorphic type of malignant fibrous histiocytoma" was diagnosed based on both the microscopic and immunohistochemical findings. The patient presented with multiple bilateral lung metastasis three years after nephrectomy.

Histopathological examination is essential since malignant fibrous histiocytoma cannot be differentiated clinically and radiologically from other lesions with kidney involvement. The overall prognosis is unfavorable with a recurrence rate of more than $50 \%$ and the 5 -yearsurvival rate is only $14 \%$.

Key Words: Kidney, Malignant fibrous histiocytoma, Diagnosis, Metastasis
ÖZ

Böbreğin primer malign fibröz histiyositomu oldukça nadir görülen bir tümördür. Radikal cerrahiye rağmen lokal rekürens riskinin yüksek olması nedeniyle prognozu genel olarak kötüdür. 43 yaşında bayan hastada sol böbrek yerleşimli bir primer renal malign fibröz histiyositom olgusunu sunduk.

Sol yan ağrısı yakınması ile gelen hastanın abdomenin ultrasonografisi vebilgisayarlıtomografisinde 10x9x7 cmboyutlarında, lobülekontürlü, iyi sınırlı renal kitle saptandı. Diğer böbrek ve renal fonksiyonlar normal idi. Bu kitlenin metastaz olabileceği düşünülerek yapılan taramada birincil tümör odağı bulunamadı. Ancak, karaciğerde bir odakta metastaz ile uyumlu kitle saptandı. Hastaya sol radikal nefrektomi uyguland. Materyalin makroskopik incelemesinde renal parankim, perirenal yağ doku ve adrenal dokusunu infiltre eden $12 \times 11 \times 8 \mathrm{~cm}$ boyutlarında solid, sarı-beyaz renkte, kısmen nekrotik tümör dokusu izlendi. Mikroskopik olarak tümör, yaygın şekilde nekrotik idi, fasiküler ve storiform yapılar oluşturmuş, pleomorfik, iğsi ve poligonal hücrelerden oluşmaktaydı. 10 büyük büyütme alanında 12 mitoz saptand. İmmünohistokimyasal boyamada vimentin ve CD68 ile pozitif boyanma görülürken pansitokeratin, düz kas aktin, S-100, HMB-45 ve desmin antikoru ile negatif boyanma görüldü. Mikroskopik ve immünohistokimyasal bulgular ile olguya "malign fibröz histiyositom, pleomorfik tip" tanısı konuldu. Nefrektomiden üç yıl sonra hastada multipl bilateral akciğer metastazları ortaya çıktı. Primer renal malign fibröz histiyositom diğer yaygın renal kitle yapan hastalıklardan klinik ve radyolojik olarak ayırt edilemediği için histopatolojik inceleme gereklidir. Prognoz, olguların yarısından fazlasında rekürrens görülmesi nedeniyle kötüdür ve 5 yıllık yaşam oranı sadece \%14'tür.

Anahtar Sözcükler: Böbrek, Malign fibröz histiyositom, Tanı, Metastaz 


\section{INTRODUCTION}

Malignant fibrous histiocytoma is the most common soft tissue sarcoma in adults (1). It has first been described by O'Brien and Stout in 1964 and originates from primitive mesenchymal cells with histiocytic and fibroblastic differentiation (2). The typical locations are the extremities (67-75\%) and the retroperitoneum (6-16\%) (3). Malignant fibrous histiocytomas with a primary in the kidney are quite rare and very few cases have been reported.

\section{CASE REPORT}

A 43-year-old female presented with left flank pain for the last 3-4 months. Physical examination revealed a left costovertebral region mass that was painful on palpation. Laboratory tests showed anemia and a high ESR. Lower abdominal CT and MR revealed a 10x9x7 $\mathrm{cm}$ solid left renal mass with heterogenous contrast enhancement that had a lobulated contour. Upper abdominal CT showed a mass consistent with metastasis at one hepatic focus. Left radical nephrectomy was performed via thoracoabdominal incision.

The material was macroscopically $13 \times 11 \times 10 \mathrm{~cm}$ in size and consisted of kidney, perirenal fat and left adrenal tissues. The surface of the incision showed a tumor surrounding most of the renal parenchyma with a size of $12 \times 11 \times 8 \mathrm{~cm}$ that extended outside the renal capsule and into Gerota's fascia and also invaded the adjacent adrenal gland. The yellow-white tumor had multifocal necrotic areas and showed scattered hemorrhages. Tumor was also present on the ureter on the nephrectomy material (Figure 1).

Histopathological investigation showed tumoral proliferation with a fascicular and storiform pattern between large necrosis areas (Figure 2). Tumor cells were large, pleomorphic, oval, and vesiculated with a spindle-shaped hyperchromatic nucleus in some places and multinuclear in others (Figure 3 ). There were 12 mitoses, some atypical, in 10 high power fields. The results of immunohistochemical testing of the tumoral cells to exclude sarcomatoid renal cell carcinoma, leiomyosarcoma and other mesenchymal tumors were as follows: vimentin positive, and pancytokeratin, desmin, smooth muscle actin, HMB-45, S-100 negative. There were some CD68-positive histiocytes. The tumor had extensively invaded perirenal fatty tissue, the left adrenal gland, renal pelvis and ureter. These morphological and immunohistochemical findings and lack of another tumor in retroperitoneal or soft tissue location led to the diagnosis of primary renal malignant fibrous histiocytoma, Grade 2 (according to FNCLCC).

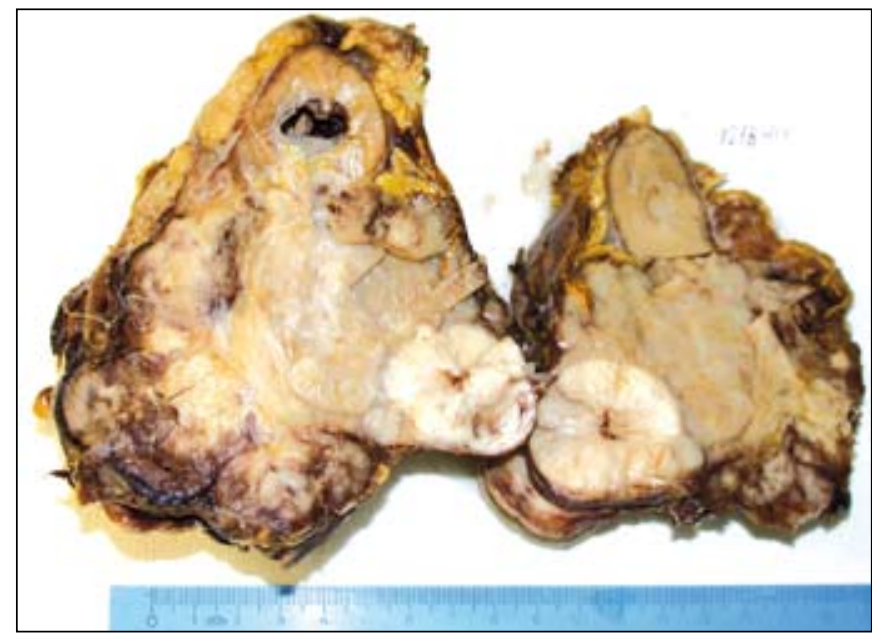

Figure 1: Yellow-white solid mass with a heterogenous cut surface containing areas of necrosis and hemorrhage and invading perirenal fatty tissue, adrenal gland and renal pelvis.

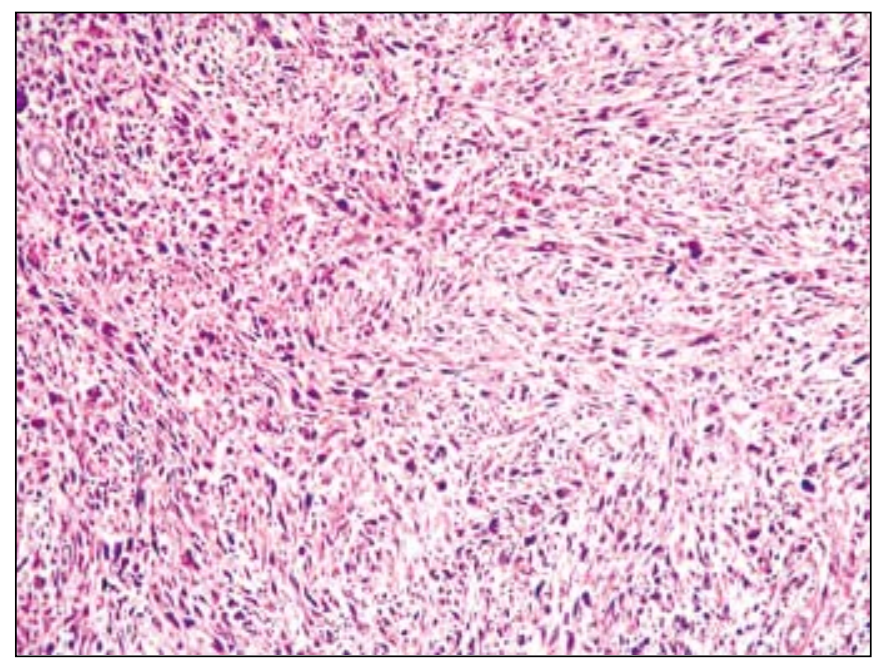

Figure 2: Fibriohistiocytic cell proliferation with a storiform pattern $(H \& E, x 100)$.

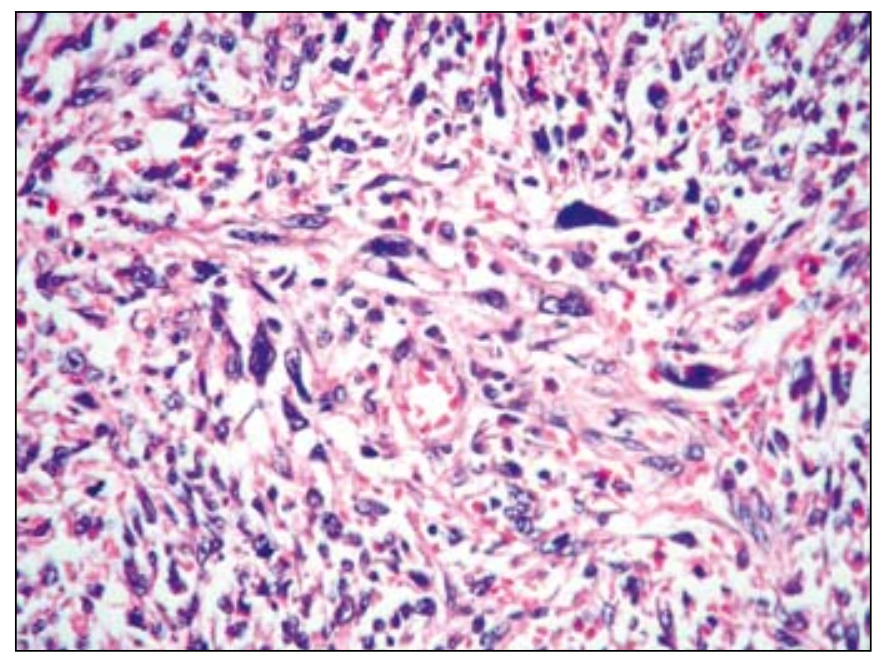

Figure 3: Marked nuclear pleomorphism and atypical appearance of tumor cells (H\&E, x400). 
Our case received postoperative chemotherapy and has been followed up for the last two years. His last presentation at our hospital was 36 months after surgery. There was nothing to support recurrence at the postoperative site on tests but thorax CT showed multiple metastatic lesions of both lungs. Chemotherapy was started for the metastases.

\section{DISCUSSION}

Primary sarcomas of the kidney make up 1-3\% of renal tumors $(4,5)$. Primary renal malignant fibrous histiocytoma originating from the renal parenchyma or capsule makes up less than $6 \%$ of renal sarcomas $(5,6,7)$. This entity may be confused with other malignant renal tumors clinically and radiologically and peaks at the 5th to 7 th decades with equal sex distribution (8). It most commonly affects the left kidney (8). Patients present with nonspecific symptoms such as flank pain, fever, weight loss, a palpable mass and rarely hematuria $(9,10)$. There are no specific radiological findings of the tumor and definite diagnosis requires histopathological investigation $(8,9)$. There are four major histological subtypes: the storiform-pleomorfic type, giant cell type, myxoid type and inflammatory type (1). Our case showed the storiform-pleomorfic pattern, the most common histological type (2). It is difficult to clinically and radiologically differentiate primary renal storiformpleomorfic type malignant fibrous histiocytomas from retroperitoneal malignant fibrous histiocytomas, other sarcomas, sarcomatoid carcinomas and renal cell carcinomas of the kidney (3). A retroperitoneal location, one of the typical locations of malignant fibrous histiocytomas, physical examination and radiological scanning of the extremities and good macroscopic evaluation of the mass seen on the nephrectomy material provide good clues regarding the primary of the tumor. Although it may be difficult to differentiate these lesions from other primary sarcomatous lesions of the kidney (leiomyosarcoma, liposarcoma, fibrosarcoma, rhabdomyosarcoma and malignant schwannoma) immunohistochemical CD 68 positivity is specific to malignant fibrous histiocytoma (3). We found desmin, smooth muscle actin, HMB-45 and S-100 (-) in our patient in tests performed for differential diagnosis. Another lesion that should be considered is the sarcomatoid variant of renal cell carcinoma. None of the multiple samples from the $12 \times 11 \times 10 \mathrm{~cm}$ mass of our case showed morphology supporting renal cell carcinoma and the negative EMA and pancytokeratin immunohistochemistry also supported the diagnosis of malignant fibrous histiocytoma (3).
In conclusion, primary renal malignant fibrous histiocytoma is a high-grade tumor with unfavorable prognosis (11). It is difficult to differentiate clinically and radiologically from other primary renal tumors and the definite diagnosis can only be made by histopathology $(8,9)$. The best treatment is radical nephrectomy to which chemoradiotherapy can be added $(9,12)$. The local recurrence and distant metastasis risk is high despite all the treatment options (13). The most common distant metastasis sites are the lungs, lymph nodes, bone and liver (14). Our case also had findings consistent with metastasis at a hepatic focus at the time of diagnosis. Thoracic CT 36 months after surgery revealed multiple metastatic lesions in both lungs.

\section{REFERENCES}

1. Malignant fibrohistiyocytic tumors. In Weiss SW, Goldblum JR (eds): Enzinger and Weiss's Soft Tissue Tumors, 4th ed. St Louis, Mosby, 2001, 535-570

2. O'Brien JE, Stout AP: Malignant fibrous xanthomas. Cancer 1964, 17:1445-1456

3. Takashi M, Murase T, Kato K, Koshikawa T, Mitsuya $H$ : Malignant fibrous histiocytoma arising from the renal capsule: report of a case. Urol Int 1987, 42:227-230

4. Farrow GM, Harrison EG Jr, Utz DC: Sarcomas and sarcomatoid and mixed malignant tumors of the kidney in adults. Cancer 1968, 22:556-563

5. Gupta R, Gupta S, Aggarwal D, Singh S: Primary pleomorphic undifferentiated sarcoma of the kidney: a rare renal tumor. Indian J Pathol Microbiol 2008, 51: 573-576

6. Takahashi S, Tsukamoto T, Lieber M: Genitorinary sarcomas in adults. In: Vogelzang NJ (ed): Comprehensive Textbook of Oncology, St Louis, Williams and Wilkins, 1992, 1124-1139

7. Shirkhoda A, Lewis E: Renal sarcoma and sarcomatoid renal cell carcinoma: CT and angiographic features. Radiology 1987, 162:353-357

8. Tarján M, Cserni G, Szabó Z: Malignant fibrous histiocytoma of the kidney. Scand J Urol Nephrol 2001, 35:518-520

9. Ptochos A, Karydas G, Iosifidis N, Tyrothoulakis E, Papazafiriou G, Kehagia-Koutoufari T: Primary renal malignant fibrous histiocytoma: a case report and review of the literature. Urol Int 1999, 63: 261-267

10. Ghosh A, Dwivedi US, Kumar A: Inflammatory malignant fibrous histiocytoma of kidney: a case report. Pathol Res Pract 2008, 204: 857-861

11. Lopez JI, Angulo JC, Flores N, Toledo JD: Malignant fibrous histiocytoma of the renal capsule and synchronous transitional cell carcinoma of the bladder. Pathol Res Pract 1996, 192: 468471

12. Papadopoulos I, Rudolph P: Primary renal malignant fibrous histiocytoma: case report. Urol Int 1999, 63: 136-138

13. Srivinas V, Sogani PC, Hajdu SI, Whitmore WF Jr: Sarcomas of the kidney. J Urol 1984, 132: 13-16

14. Répássy D, Csata S, Sterlik G, Hazslinszky P: Retroperitoneal malignant fibrous histiocytoma. Int Urol Nephrol 1999, 31: 303 311 